\title{
Monoclonal B-cell lymphocytosis
}

\author{
G. D’Arena ${ }^{1}$, P. Musto ${ }^{2}$ \\ ${ }^{1}$ Hematology and Stem Cell Transplantation Unit \\ ${ }^{2}$ Scientific Direction, IRCCS, Centro di Riferimento Oncologico della Basilicata, Rionero in Vulture (Pz), Italy \\ (giovannidarena@libero.it)
}

\begin{abstract}
Monoclonal B-cell lymphocytosis (MBL) is an asymptomatic hematologic condition defined by the presence of a small $\left(<5 \times 10^{9} / \mathrm{L}\right)$ clonal B-cell population in the peripheral blood in the absence of lymph-node enlargement, cytopenias or autoimmune diseases. It is found in approximately $3-12 \%$ of normal persons depending on the accuracy of analytical techniques applied. According to the immunophenotypic profile of clonal B-cells, the majority of MBL cases $(\mathbf{7 5 \%})$ are classified as chronic lymphocytic leukemia (CLL)-like. This form may progress into CLL at a rate of $1-2 \%$ per year. It is thought that CLL is always preceded by MBL. The remaining MBL cases are defined as atypical CLL-like (CD5+/CD20 ${ }^{\text {bright }}$ ) and CD5 ${ }^{-}$MBL. The MBL clone size is quite heterogenous. Accordingly, two forms of MBL are identified: i) high-count, or 'clinical' MBL, in which an evidence of lymphocytosis ( $<5 \times 10^{9} / \mathrm{L}$ clonal B-cells) is seen, and ii) a low-count MBL, in which a normal leukocyte count is found and that is identified only in population-screening studies. Both forms of MBL may carry the cytogenetic abnormalities that are the hallmark of CLL, including 13q-, 17p- and trisomy 12. Consistent with the indolent phenotype of this condition, genetic lesions, such as TP53, ATM, NOTCH1 and SF3B1 mutations, usually associated with high-risk CLL, are rarely seen. Overall, no prognostic indicator of evolution of MBL to overt CLL has been found at present time. However, taking into account this possibility, a clinical and lab monitoring (at least annually), is recommended.
\end{abstract}

Keywords: Monoclonal B-cell lymphocytosis, chronic lymphocytic leukemia, diagnostic criteria, management

\section{INTRODUCTION}

Monoclonal B-cell lymphocytosis, or MBL for short, is an asymptomatic condition characterized by the presence of a circulating small clonal B-lymphocyte population in persons who do not have chronic lymphocytic leukemia (CLL), other B-cell lymphoproliferative disorder, or underlying conditions such as infectious or autoimmune disorders [1].

Despite the fact that the majority of subjects diagnosed with MBL does not develop CLL [2,3], a large population-based cancer study suggests that MBL may precedes CLL by several years in some cases [4]. Efforts are on-going to identify at molecular level patients with MBL at higher risk of developing CLL in order to design intervention approaches able to delay or prevent CLL progression.

\section{WHAT IS MBL}

MBL has been defined as an asymptomatic condition characterized by an expansion of circulating clonal B-cell lymphocytes (less than $5 \times 10^{9} / \mathrm{L}$ ) in patients with no symptoms or signs of lymphoproliferative disorders, such as lymph-node enlargement a and/or hepato-splenomegaly (Table 1) [1,2,5-7]. Moreover, MBL may be classified as follows, according to the immunophenotypic profile of clonal cells:

i) CLL-like phenotype ( $75 \%$ of cases), in which cells are indistinguishable from that of CLL cases in that they coexpress CD5, CD19, CD23, and $\mathrm{CD} 20^{\mathrm{dim}}$, and with surface immunoglobulin (sIg) expression at low levels;

ii) atypical CLL phenotype: CD5 and CD19 coexpression, CD20 ${ }^{\text {bright }}$ expression and/or CD23 negativity, light chain restriction with moderate/bright sIg expression;

iii) non-CLL phenotype: CD5 negativity, expression of CD20, light chain restriction with moderate/bright sIg expression. In atypical forms, it is mandatory to exclude $\mathrm{t}(11 ; 14)$ to rule out mantle cell lymphoma.

TABLE I. DIAGNOSTIC CRITERIA FOR MONOCLONAL B-CELL LYMPHOCYTOSIS (MBL)

1) Detection of a monoclonal B-cell population in the peripheral blood with light chain restriction

2) Presence of a disease-specific immunophenotype

3) Absolute B-cell count less than $5 \times 10^{9} / \mathrm{L}$

4) No other features of lymphoproliferative disorder (no lymph nodes, spleen and/or liver enlargement, no B-symptoms, such as fever, weight loss or nighttime sweating)

5) No autoimmune or infectious disease

The differential diagnosis includes small lymphocytic lymphoma (SLL), where the number of circulating neoplastic B-cells may be less than $5 \times 10^{9} / \mathrm{L}$. However, the presence of lymph nodes, liver or spleen enlargement is a typical feature of SLL (Table 2).

Gibson et al. have also proposed the definition of 'nodal MBL' to indicate a subsets of patients with fewer than $5 \times 10^{9} / \mathrm{L}$ circulating clonal B-lymphocytes and a focal/subtle abnormal CLL-like infiltration [8].

Based on the observation that the absolute number of B-cells identifies those patients who will require treatment from those patients who will not better than the absolute lymphocyte count, in 2008 the diagnostic criteria of CLL 
have been revised setting the diagnostic threshold of neoplastic B-cells in peripheral blood to higher than $5 \mathrm{x}$ $10^{9} / \mathrm{L}$ [7]. As a matter of the fact, a significant number of patients previously recognized as having Rai stage 0 CLL have been re-classified with CLL-like MBL. Thus, the distinction between MBL and Rai stage 0 CLL resides only on the number of absolute neoplastic B-cells. Moreover, Landgren et al. demonstrated that virtually all patients with CLL have a CLL-type MBL phase several years before the CLL diagnosis [5]. Several researchers have tried to compare the outcome of the two forms of lymphoproliferative disorders [3,4,9-13]. Fung et al. showed that Rai stage 0 CLL patients and CLL-type MBL patients had a similar overall survival, but also that CLLtype MBL group displayed a lower probability of early progression [9]. No difference was found by Faguet et al.

TABLE II. DIFFERENTIAL DIAGNOSIS AMONG CLL, MBL AND SLL

\begin{tabular}{lcc}
\hline & $\begin{array}{c}\text { Neoplastic B-cells } \\
<5 \times 10^{9} / \mathrm{L}\end{array}$ & $\begin{array}{c}\text { Lymph nodes and/or spleen } \\
\text { and/or liver enlargement }\end{array}$ \\
\hline MBL & + & - \\
CLL & - & $+/-$ \\
SLL & + & + \\
\hline
\end{tabular}

in terms of disease progression [10]. Shanafelt et al. observed no difference in overall survival; however, these authors found that fewer MBL patients required treatment and time to treatment was found to be directly correlated with the absolute B-cell count [4]. Rawstron et al. also did not find any association with overall survival or time to first treatment; in this study, however, the Bcell count at the time of MBL diagnosis was the only independent predictive factor of progression in terms of lymphocytosis [3]. More recently, Rossi et al reported a longer treatment-free survival in MBL patients than in Rai stage 0 CLL [11]. Finally, an absolute B-cell count ranging from 10 to $11 \times 10^{9} / \mathrm{L}$ was demonstrated to better predict the clinical outcome (time to first treatment), thus suggesting that the threshold of $5 \times 10^{9} / \mathrm{L}$ B-cells might be inadequate $[12,13]$.

Taken together, these data indicate that the number of circulating B-cells is a strong predictor of outcome for MBL patients and that "clinical" MBL, with respect to "low count" MBL, is closely related to CLL and may be considered as an early-stage CLL [14].

\section{BIOLOGY OF MBL}

MBL are more common than CLL (see section IV) and, as above reported, it is thought that almost always they precede CLL [5]. Therefore, it is evident that only a small population of MBL patients evolve into overt CLL overtime. Ghia and Caligaris-Cappio very recently reviewed this topic and proposed that the encounter of a
B-cell carrying intrinsic abnormalities with an appropriate external stimulus (i.e., antigen/B-cell receptor interaction) may trigger the clonal development of MBL [14]. On the other hand, the possibility that external stimuli may precede and favors the appearance of genetic abnormalities also exists. Finally, the persistence of an antigenic stimulus inducing enhanced clone proliferation could favors the acquisition of additional genetic abnormalities with the possibility that some MBL may progress into overt CLL. Interestingly, in hepatitis C-virus (HCV) infected patients MBL has been detected in $28,5 \%$ of subjects [15]. Moreover, its frequency was found increased in patients with more advanced disease.

Either clinical and population-screening studies indicate that MBL, mimicking what observed in monoclonal gammopathy of undetermined significance (MGUS), display the same chromosomal abnormalities and a mutated IgVH status usually seen in low-risk CLL $[3,11,13,16-18]$. The biological indolent behavior of MBL is also documented by the rare occurrence of genetic lesions predicting poor prognosis in CLL, such as TP53, ATM, NOTCH1 and SF3B1 mutations [17-21]. These mutations are, in fact, more frequently detected in the later stages of CLL and in Richter syndrome transformation [22].

Regulatory T-cells (Tregs) constitute a small subset of cells involved in antitumour immunity and are generally increased in patients with CLL [23]. Tregs have been found higher in 'clinical' MBL patients with respect to healthy subjects, but lower than in CLL patients [24]. It has been hypothesized that the progressive increase of Treg numbers might contribute both to the clinical evaluation of MBL to overt CLL and to CLL progression.

\section{PREVALENCE OF MBL}

The prevalence of MBL in general population has been extensively investigated in large population-based studies [1,3,25-29]. As showed in Figure 1, the reported prevalence varied widely, ranging from $0.6 \%$ to $12 \%$. This very large variability is closely related to the methodology used to detect MBL cells, in particular the number of monoclonal antibodies used (the higher number is employed, the higher incidence of MBL is found) and that of cells evaluated. In fact, the highest incidence was found by Salamanca group study in which eight-color staining panels were utilized and a greater number of cells analyzed (5 million per case versus 200.000 to 500.000 in the other studies) [28].

Interestingly, in a study performed to investigate the potential health effects of living around hazardous waste sites in the United States [30], the authors suggested that MBL may be a potentially useful biomarker for investigating environmental exposures potentially associated with chronic lymphoproliferative disorders, such as CLL. Furthermore, the highest prevalence of CLL-like form of MBL was found in first-degree relatives 
of CLL patients, thus suggesting a higher risk of developing CLL in these subjects [31].

\section{NATURAL HISTORY OF MBL AND MANAGEMENT}

Whether CLL needs of a MBL preceding phase before to develop is still matter of debate. Landgren et al, analyzing data from 77,469 healthy adults enrolled in the nationwide, population-based Prostate, Lung, Colorectal, and Ovarian (PLCO) Cancer Screening Trial, identified 45 subjects who were diagnosed with CLL up to 6.4 years later [5]. By evaluating stored peripheral blood samples, these authors were able to demonstrate that 44 out of 45 patients with CLL had a preceding MBL phase, thus suggesting that CLL is almost always preceded by a precursor condition, such as MBL.

Thus, MBL may progress to overt CLL and several investigators tried to estimate the frequency of this phenomenon [3,4,11]. However, the risk of transformation to CLL requiring therapy is very low in 'clinical' MBL, accounting for $1-2 \%$ per year, and extremely rare in research population-screening MBL [17]. Moreover, no specific therapy is established for MBL to date and only watch and wait approach for clinical MBL is required due to the above mentioned very low possible evolution to overt CLL overtime.
For that reasons, physical examination, patient history, whole blood cell count and flow cytometry of peripheral blood are mandatory to establish the diagnosis of MBL. The majority of investigators recommend a clinical and lab (physical examination for lymphadenopathy and complete blood cell count with differential) evaluation every 6 to 12 months for patients with 'clinical' MBL, according to the number of circulating clonal B.cells (Table 3). In fact, Rawstron et al showed that more than $90 \%$ of subjects with CLL-like MBL and a cell count below $1900 \times 10^{9} / \mathrm{L}$ will have a stable lymphocytosis over a 5-year period [3]. On the other hand, subjects with more than $1900 \times 10^{9} / \mathrm{L}$ clonal B.cells show no disease progression Kaplan-Meier curves plateau over time, suggesting the need of continue monitoring in these MBL [32,33].

\section{CONCLUSION}

Progresses in flow cytometry with developing of more and more highly sensitive techniques have make possible to detect abnormal small B-cell clones in otherwise asymptomatic subjects. In the so-called 'lowcount' MBL the risk of progression to overt CLL/SLL is very low and the disease remains stable over time.

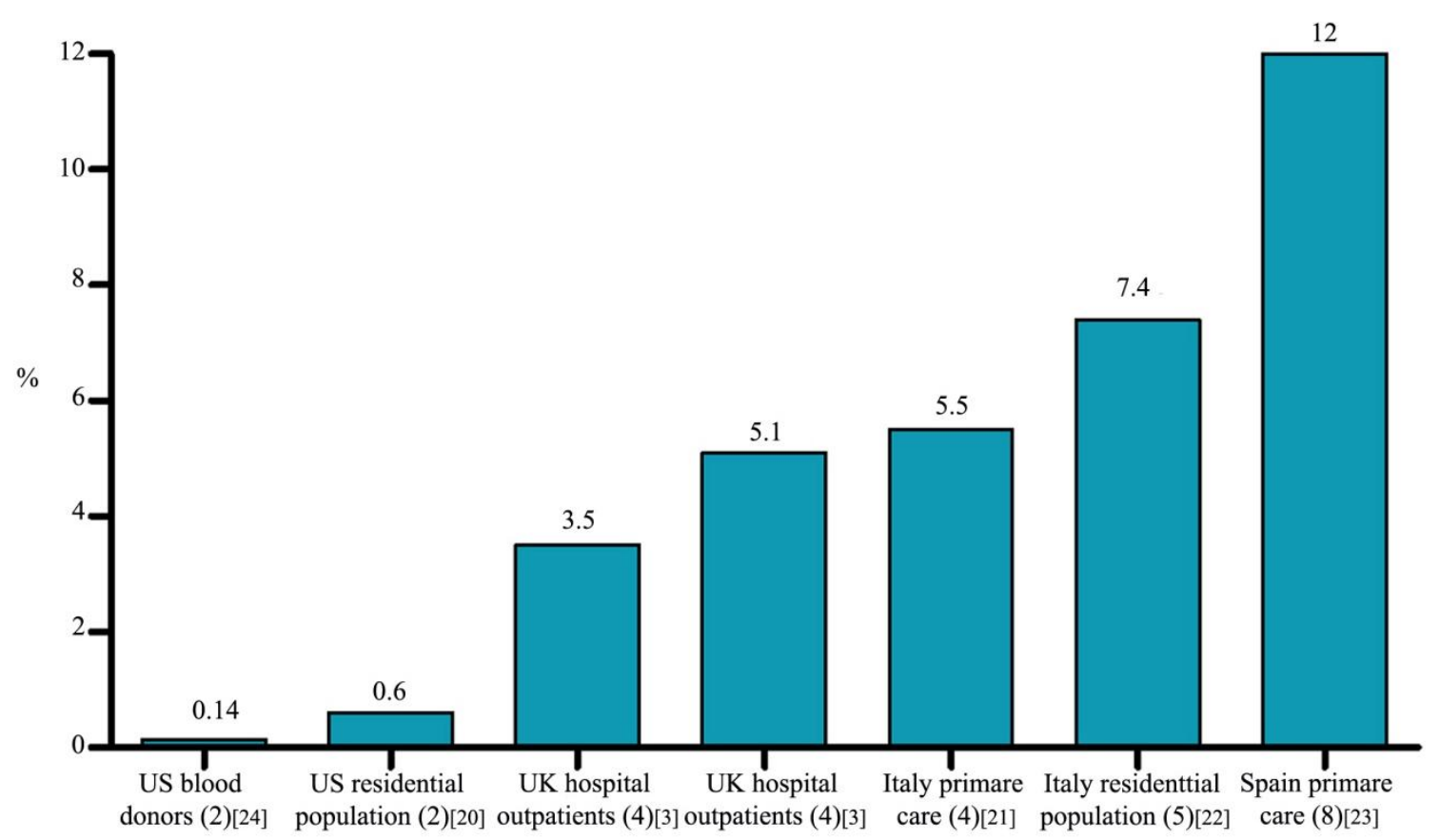

Figure 1. Prevalence of MBL. Figures on the top of bars showed the incidence (\%) of MBL. Figures (in brackets) in $\mathrm{x}$-axis showed the number of monoclonal antibodies used to detect MBL clone. 
TABLE III. FOLLOW-UP OF MBL CASES ACCORDING TO THE NUMBER OF CLONAL B-CELLS

\begin{tabular}{l|l|l} 
GROUP & \multicolumn{1}{|c|}{ INTERVAL } & METHODOLOGY \\
\hline$<1.9 \times 10^{9} / \mathrm{L}$ & $\begin{array}{l}\text { Once within 6-12 } \\
\text { months }\end{array}$ & $\begin{array}{l}\text { Differential blood } \\
\text { cell count, } \\
\text { immunophenotyping, } \\
\text { clinical examination }\end{array}$ \\
\hline$\geq 1.9 \times 10^{9} / \mathrm{L}$ & $\begin{array}{l}\text { Regularly every 6-12 } \\
\text { months }\end{array}$ & $\begin{array}{l}\text { Differential blood } \\
\text { cell count, } \\
\text { immunophenotyping, } \\
\text { clinical examination }\end{array}$ \\
\hline
\end{tabular}

On the contrary, in 'clinical' MBL the risk of progression is estimated to be approximately $1-2 \%$ per year. No prognostic parameter able to identify subjects more prone to evolution compared to subjects with more stable lymphocytosis has been so far identified. For that reasons, a monitoring of lymphocytosis and/or lymphadenopathy at least annually is recommended.

\section{REFERENCES}

[1] Shanafelt TD, Ghia P, Lanasa MC, Landgren O, Rawstron AC. Monoclonal B-cell lymphocytosis (MBL): biology, natural history and clinical management. Leukemia 2010; 24: 512-520.

[2] Marti GE, Rawstron AC, Ghia P, Hillmen P, Houlston RS, Kay N, Schleinitz TA, Caporaso N; International Familial CLL Consortium. Diagnostic criteria for monoclonal B-cell lymphocytosis. Br J Haematol 2005; 130: 325-332.

[3] Rawstron AC, Bennett FL, O’Connor SJ, Kwok M, Fenton JA, Plummer M, de Tute R, Owen RG, Richards SJ, Jack AS, Hillmen P. Monoclonal B-cell lymphocytosis and chronic lymphocytic leukemia. N Engl J Med 2008; 359: 575-583

[4] Shanafelt TD, Kay NE, Rabe KG, Call TG, Zent CS, Maddocks K, Jenkins G, Jelinek DF, Morice WG, Boysen J, Schwager S, Bowen D, Stager SL, Hanson CA. Brief report: natural history of individuals with clinically recognized monoclonal B-cell lymphocytosis compared with patients with Rai 0 chronic lymphocytic leukemia. J Clin Oncol 2009; 27: 3959-3963.

[5] Landgren O, Albitar M, Ma W, Abbasi F, Hayes RB, Ghia P, Marti GE, Caporaso NE. B-cell clones as early markers for chronic lymphocytic leukemia. N Engl J Med 2009; 360: 659-667.

[6] Müller-Hermelink HK, Montserrat E, Catovsky D. In: Sweldlow SH, Campo E, Harris NL, et al, editors. WHO classification of tumours of hematopoietic and lymphoid tissues. Lyon (France): International agency for research on cancer; 2008; pp180-182.

[7] Hallek M, Cheson BD, Catovsky D, Caligaris-Cappio F, Dichiero G, Döhner H, Hillmen P, Keating MJ, Montserrat E, Rai KR, Kipps TJ. Guidelines for the diagnosis and treatment of chronic lymphocytic leukemia updating the National cancer Institute-Working Group 1996 guidelines. Blood 2008; 111: 5446-5456.

[8] Gibson SE, Swerdlow SH, Ferry JA, Surti U, Dal Cin P, Harris NL, Hasserjian RP. Reassessment of small lymphocytic lymphoma in the era of monoclonal B-cell lymphocytosis. Haematologica 2011; 96: 1144-1152.

[9] Fung SS, Hillier KL, Leger CS, Sandhu I, Vickars LM, Galbraith PF, Li $\mathrm{CH}$, Leitch HA. Clinical progression and outcome of patients with monoclonal Bcell lymphocytosis. Leuk Lymphoma 2007; 48: 10871091.

[10] Faguet GB, Agee JF, Marti GE. Clone emergence and evolution in chronic lymphocytic leukemia: characterization of clinical, laboratory and immunophenotypic profiles of 25 patients. Leuk Lymphoma 1992; 6: 346-356.

[11] Rossi D, Sozzi E, Puma A, De Paoli L, Rasi S, Spina V, Gozzetti A, Tassi M, Cencini E, Raspadori D, Pinto V, Bertoni F, Gattei V, Lauria F, Gaidano G, Forconi F. The prognosis of clinical monoclonal B cell lymphocytosis differs from prognosis of Rai 0 chronic lymphocytic leukemia and is recapitulated by biological risk factors. $\mathrm{Br}$ J Haematol 2009; 146: 64-75.

[12] Molica S, Mauro FR, Giannarelli D, Lauria F, Cortelezzi A, Brugiatelli M, Liso V, Cuneo A, Foà R. Differentiating chronic lymphocytic leukemia from monoclonal B-lymphocytosis according to clinical outcome: on behalf of the GIMEMA chronic lymphoproliferative diseases working group Haematologica 2011; 96: 277-283.

[13] Shanafelt TD, Kay NE, Jenkins G, Call TG, Zent CS, Jelinek DF, Morice WG, Boysen J, Zakko L, Schwager S, Slager SL, Hanson CA. B-cell count and survival: differentiating chronic lymphocytic leukemia from monoclonal B-cell lymphocytosis based on clinical outcome. Blood 2009; 113: 4188-4196.

[14] Kern W, Bacher U, Haferlach C, Dicker F, Alpermann T, Schnittger S, Haferlach T. Monoclonal Bcell lymphocytosis is closely related to chronic lymphocytic leukaemia and may be better classified as early-stage CLL. Br J Haematol 2012; 157: 89-96.

[15] Fazi C, Dagklis A, Cottini F, Scarfò L, Bertilaccio MT, Finazzi R, Memoli M, Ghia P. Monoclonal B cell lymphocytosis in hepatitis $\mathrm{C}$ virus infected individuals. Cytometry B Clin Cytom 2010; 78 (Suppl 1): 561-568.

[16] Ghia P, Caligaris-Cappio F. Monoclonal B-cell lymphocytosis: right track or red herring? Blood 2012; 119: 4358-4362.

[17] Molica S, Fabris S, Cutrona G, Matis S, Pesce EA, Maura F, Ciceri G, Di Raimondo F, Musolino C, Gobbi M, Di Renzo N, Mauro FR, Cantaffa R, Brugiatelli M, Merli F, Zupo S, Mammi C, Baldini L, Angrilli F, Quintana G, Consoli U, Iannitto E, Di Tonno P, Fragasso A, Musto P, Cox M, Festini G, Callea, Sacchi S, Cortelezzi A, Lambertenghi Deliliers G, Foà R, Federico M, Neri A, Ferrarini M, Morabito R. Differentiation on biological basis of monoclonal B-cell lymphocytosis 
(MBL) from chronic lymphocytic leukemia (CLL): results of a prospective GISL (Gruppo Italiano Linfomi) trial. Blood 2010; 116 (Suppl 1): Abstr 13260.

[18] Molica S, Mauro FR, Molica M, Del Giudice I, Foà R. Monoclonal B-cell lymphocytosis: a reappraisal of its clinical implication. Leuk Lymphoma 2012; 53: 16601665 .

[19] Scarfò L, Fazi C, Ghia P. MBL versus CLL. How important is the distinction? Hematol Oncol Clin N Am 2013; 27: 251-265.

[20] Rasi S, Monti S, Spina V, Foà R, Gaidano G, Rossi D. Analysis of NOTCH1 mutations in monoclonal B-cell lymphocytosis. Haematologica 2012 Jan; 97(1): 153-154.

[21] Greco M, Capello D, Bruscaggin A, Spina V, Rasi S, Monti S, Ciardullo C, Cresta S, Fangazio M, Gaidano G, Foà R, Rossi D. Analysis of SF3B1 mutations in monoclonal B-cell lymphocytosis. Hematol Oncol 2013; 31: 54-55.

[22] Rossi D, Rasi S, Spina V, Bruscaggin A, Monti S, Ciardullo C, Deambrogi C, Khiabanian H, Serra R, Bertoni F, Forconi F, Laurenti L, Marasca R, Del-Bo M, Rossi FM, Bulian P, Nomdedeu J, Del Poeta G, Gattei V, Pasqualucci L, Rabadan R, Roà R, Dalla-Favera R, Gaidano G. Integrated mutational and cytogenetic analysis identifies new prognostic subgroups in chronic lymphocytic leukemia. Blood 2013; 121: 1403-1412.

[23] D’Arena G, Laurenti L, Minervini MM, Deaglio S, Bonello L, De Martino L, De Padua L, Savino L, Tarnani M, De Feo V, Cascavilla N. Regulatory T-cell number is increased in chronic lymphocytic leukemia patients and correlates with progressive disease. Leuk Res 2011; 35 : 363-368.

[24] D’Arena G, Rossi G, Minervini MM, Savino L, D’Auria F, Laurenti L, Del Principe MI, Deaglio S, Biagi A, De Martino L, De Feo V, Cascavilla N, Musto P, Del Poeta G. Circulating regulayory $T$ cells in 'clinical' monoclonal B-cell lymphocytosis. Int J Immunopathol Pharmacol 2011; 24(4): 915-923.

[25] Shim YK, Vogt RF, Middleton D, Abbasi F, Slade B, Lee KY, Marti GE. Prevalence and natural history of monoclonal and polyclonal B-cell lymphocytosis in a residential adult population. Cytometry B Clin Cytom 2007; 72: 344-353.

[26] Ghia P, Prato G, Scielzo C, Stella S, Geuna M, Guida G, Caligaris-Cappio F. Monoclonal CD5+ and Cd5- Blymphocyte expansion are frequent in the peripheral blood of the elderly. Blood 2004; 103: 2337-2342.

[27] Dagklis A, Fazi C, Sala C, cantarelli V, Scielzo C, Massacane R, Toniolo D, Caligaris-Cappio F, Stamatopoulos K, Ghia P. The immunoglobulin gene repertoire of population CLL-like MBL is different from CLL: diagnostic implications for clinical monitoring. Blood 2009; 114: 26-32.

[28] Nieto WG, Almeida J, Romero A, Teodosio C, Lopez A, Henriques AF, Sánchez ML, Jara-Acevedo M, Rasillo A, González M, Fernández-Navarro P, Vega T, Orfao A. Increased frequency $(12 \%)$ of circulating chronic lymphocytic leukemia-like B-cell clones in healthy subjects using a highly sensitive multicolor flow cytometry approach. Blood 2009; 114: 33-37.

[29] Rachel JM, Zucker ML, Fox CM, Plapp FV, Menitove JE, Abbasi F, Marti GE. Monoclonal B-cell lymphocytosis in blood donors. Br J Haematol 2007; 139: 832-836.

[30] Vogt RF, Shim YK, Middleton DC, Buffler PA, Campolucci SS, Lybarger JA, Marti GE. Monoclonal Bcell lymphocytosis as a biomarker in environmental helath studies. Br J Haematol 2007; 139: 690-700.

[31] Goldin LR, Bjokholm M, Kristinsson SY, Turesson I, Landgren O. Elevated risk of chronic lymphocytic leukemia and other indolent non-Hodgkin's lymphomas among relatives of patients with chronic lymphocytic leukemia. Haematologica 2009; 94: 647-653.

[32] Rawstron AC. Monoclonal B-cell lymphocytosis. Hematology Am Soc Hematol Educ Program. 2009: 430439.

[33] Rawstron AC, Shanafelt TD, Lanasa MC, Landgren O, Hanson C, Orfao A, Hillmen P, Ghia P. Different biology and clinical outcome according to the absolute numbers of clonal B-cells in monoclonal B-cell lymphocytosis (MBL). Cytometry B Clin Cytom 2010; 78 Suppl 1: S19-23. 